\title{
Monitoring and improving the effectiveness of surface cleaning and disinfection
}

\author{
William A. Rutala PhD, MPH a,b,*, David J. Weber MD, MPH a,b \\ a Hospital Epidemiology, University of North Carolina Health Care, Chapel Hill, NC \\ ${ }^{\mathrm{b}}$ Division of Infectious Diseases, UNC School of Medicine, Chapel Hill, NC
}

Key Words:

Surface

disinfection

cleaning
Disinfection of noncritical environmental surfaces and equipment is an essential component of an infection prevention program. Noncritical environmental surfaces and noncritical medical equipment surfaces may become contaminated with infectious agents and may contribute to cross-transmission by acquisition of transient hand carriage by health care personnel. Disinfection should render surfaces and equipment free of pathogens in sufficient numbers to prevent human disease (ie, hygienically clean).
There is excellent evidence in the scientific literature that environmental contamination plays an important role in the transmission of several key health care-associated pathogens, including methicillinresistant Staphylococcus aureus (MRSA), vancomycin-resistant Enterococcus (VRE), Acinetobacter sp, norovirus, and Clostridium difficile. ${ }^{1-4}$ All of these pathogens have been demonstrated to persist in the environment for days (in some cases months), frequently contaminate the environmental surfaces in rooms of colonized or infected patients, transiently colonize the hands of health care personnel, be transmitted by health care personnel, and cause outbreaks in which environmental transmission was deemed to play a role. Importantly, a study by Stiefel et al demonstrated that contact with the environment was just as likely to contaminate the hands of health care providers as was direct contact with the patient. ${ }^{5}$ Further, admission to a room in which the previous patient had been colonized or infected with MRSA, VRE, Acinetobacter or $C$ difficile has been shown to be a risk factor for the newly admitted patient to develop colonization or infection. ${ }^{6-8}$ The purpose of this article, which is adapted from other publications, ${ }^{4,9,10}$ is to discuss the available options for monitoring environmental cleaning-disinfection and discuss methods for improving environmental cleaning-disinfection.

\footnotetext{
* Address correspondence to William A. Rutala, PhD, MPH, Hospital Epidemiology, Occupational Health, and Safety Program, Room 1001 West Wing, UNC Health Care, Chapel Hill, NC 27514.

E-mail address: brutala@unch.unc.edu (W.A. Rutala).

Publication of this article was supported by an educational grant from Clorox Healthcare, Sealed Air, and Tru-D. Content of this article was initiated and written by the authors with no input or financial support to the authors from Clorox Healthcare, Sealed Air, or Tru-D.

Conflicts of interest: Dr Rutala is a consultant for Clorox and has received honoraria from 3M. Dr Weber is a consultant for Clorox.
}

\section{IMPORTANCE OF PRODUCT AND PRACTICE}

The disinfectants used in health care facilities are 1-step products, meaning they clean and disinfectant in 1-step rather than requiring 2 independent steps (ie, cleaning, followed by disinfection). ${ }^{10}$ In general, no precleaning is necessary unless a spill or gross contamination is present, in which case cleaning precedes the use of a disinfectant. Disinfectants are intended for use on hard, nonporous surfaces; however, some products are Environmental Protection Agency (EPA)-registered for application to soft surfaces, such as hospital privacy curtains. ${ }^{11}$ Hospitals should avoid the use of noncleanable surfaces, such as fabric chairs, in clinical areas and use a cleanable covering fabric (eg, vinyl). Cleaning is an important component of the cleaning-disinfection process because dust, dirt, and organic matter interfere with the effectiveness of the disinfectant by altering the antimicrobial activity of the disinfectant or protecting the pathogen from exposure to the disinfectant. In this article, we use the term cleaning-disinfection to reference this 1-step process for cleaning and disinfecting a noncritical item. ${ }^{10}$ Cleaning refers to the removal of surface debris (eg, dust, organic material), whereas disinfection refers to the use of a disinfectant or germicide designed to kill microorganisms. Cleaning-disinfection or environmental cleaning, which refers broadly to an organized process for cleaning, disinfecting, and monitoring, ${ }^{12,13}$ is a horizontal control measure. Horizontal controls are broad-based approaches to infection prevention because they attempt reduction to all infections caused by all pathogens and include hand hygiene, environmental control, and minimizing unnecessary use of invasive devices. ${ }^{14}$ Often cleaning is enhanced by detergents and surfactants. Surfactants enhance the cleaning efficacy of the 
Table 1

Properties of an ideal disinfectant

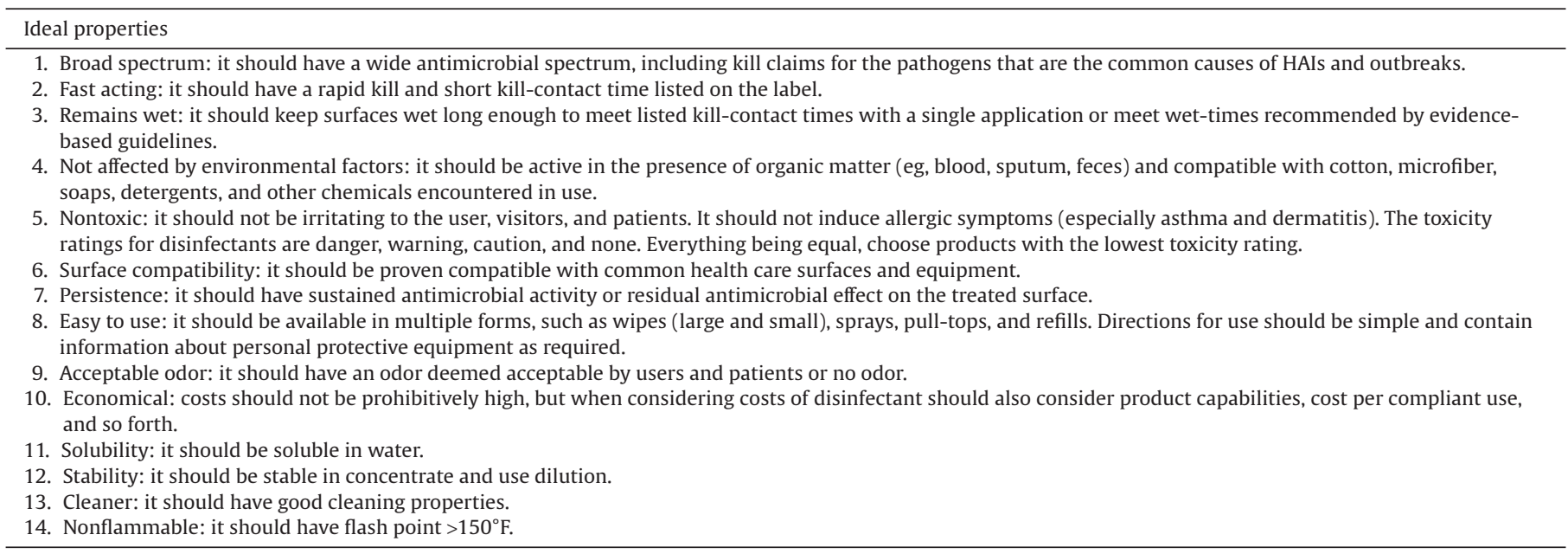

NOTE. Modified with permission from Molinari et al ${ }^{17}$ and Rutala and Weber. ${ }^{10}$

Abbreviation: HAI, health care-associated infection.

disinfectant and ensure complete and even coverage of the surface, preventing beading that occurs with some liquids. ${ }^{10,15}$ It is important to achieve even and thorough coverage of a surface to result in even and complete disinfection. Multiple studies have shown 10\%$50 \%$ of the surfaces in patient rooms colonized or infected with $C$ difficile, MRSA, and VRE are contaminated with these pathogens, and a lack of thoroughness of cleaning contaminated surfaces in patient rooms (mean $32 \%$ of objects cleaned) has been linked to an overall $120 \%$ increased risk of infection to the next occupant in that room. ${ }^{1,6,16}$

Although the process of selecting an optimal health care product or disinfectant used for low-level disinfection of noncritical items is commonplace in health care facilities, there are a very limited number of articles in the peer-reviewed literature on this topic. ${ }^{10}$ The disinfectant or the product, is 1 of the 2 components essential for effective disinfection. Table 1 identifies the characteristics of the ideal disinfectant. Studies support the use of disinfection rather than the use of a nongermicidal detergent on environmental surfaces in health care. ${ }^{18,19}$ One recent study showed that daily use of a disinfectant applied to environmental surfaces with a $80 \%$ compliance is superior to a nongermicidal detergent because it results in significantly reduced rates of health care-associated infections (HAIs) caused by $C$ difficile, MRSA, and VRE. ${ }^{20}$ Nongermicidal detergents are not recommended for multiple reasons, ${ }^{19}$ including detergent wipes transfer significant amounts of epidemiologically important pathogens (eg, MRSA, C difficile) over surfaces ${ }^{21}$ and disinfectants are more effective than detergents in reducing microbial contamination. ${ }^{22}$ Similarly, results have demonstrated efficient transfer of $C$ difficile spores from contaminated-to-clean surfaces by nonsporicidal wipes and overused sporicidal wipes. ${ }^{23}$ To date, the perfect product for health care surface disinfection has not been introduced; however, there is a wide array of excellent disinfectants that offer a range of characteristics (Table 2).

To keep patients as safe as possible, health care facilities must consider what pathogens are the most common causes of HAIs, the most common causes of outbreaks and ward closures, and the unique pathogens of their facility. The product selected should be effective against the microorganisms that are the most common causes of HAIs and outbreaks (Table 3), according to nationally reported data. Because vegetative bacteria (eg, $S$ aureus, Enterococcus, Escherichia coli, coagulase-negative Staphylococcus, Pseudomonas aeruginosa, Klebsiella spp, Enterobacter spp) are the pathogens that cause most HAIs (79.1\%), ${ }^{26,28}$ health care disinfectants should be effective against these pathogens. ${ }^{10}$

The other component, the practice, is thorough application such that the disinfectant contacts all hand-contact or touchable surfaces. It also involves proper training of hospital staff (especially environmental services and nursing) and adherence to the manufacturer's label instructions (except in the cases where an institution may prepare a formal risk assessment to follow alternate contact times such as $\geq 1$ minute for vegetative bacteria). Other factors that affect practice and performance include sufficient contact time, concentration, surface type, ease of use, organic soil and hard water, porosity of the surface, compatibility of the disinfectant with the wipe used, and sufficient cleaning time. The combination of product and practice results in effective surface disinfection, including the reduction of patient risk via microbial removal and inactivation and improved patient outcomes. ${ }^{10}$

\section{DISINFECTION USING LOW-LEVEL DISINFECTANTS}

It has long been recommended in the United States that environmental surfaces in patient rooms be cleaned and disinfected on a regular basis (eg, daily, 3 times per week), when surfaces are visibly soiled, and after patient discharge (terminal cleaning). ${ }^{29}$ There are now data that demonstrate daily disinfection of high-touch surfaces (compared with cleaning when soiled) was associated with a significant reduction in the frequency of pathogens on investigators' hands after contact with the surfaces and the mean number of bacteria acquired. ${ }^{30}$ Disinfection is generally performed using an EPA-registered hospital disinfectant, such as a quaternary ammonium compound, chlorine, or phenol (Table 2). Newer products effective against health care-associated pathogens include improved hydrogen peroxide (HP) and peracetic acid-HP. ${ }^{11,31-33}$

\section{MONITORING AND IMPROVING THE THOROUGHNESS OF CLEANING-DISINFECTION}

The cleaning-disinfection of noncritical surfaces in hospitals is essential for reducing microbial contamination and reducing HAIs. ${ }^{12,13,18}$ A recent Agency for Healthcare Research and Quality review offers an overview of the monitoring modalities, ${ }^{12,13}$ which include visual inspection, microbiologic methods, fluorescent 
Table 2

Summary of advantages and disadvantages of disinfectants used as low-level disinfectants

\begin{tabular}{|c|c|c|}
\hline Disinfectant active & Advantages & Disadvantages \\
\hline Alcohol & $\begin{array}{l}\text { - Bactericidal, tuberculocidal, fungicidal, virucidal } \\
\text { - Fast-acting } \\
\text { - Noncorrosive } \\
\text { - Nonstaining } \\
\text { - Used to disinfect small surfaces, such as rubber stoppers } \\
\text { on medication vials } \\
\text { - No toxic residue }\end{array}$ & $\begin{array}{l}\text { - Not sporicidal } \\
\text { - Affected by organic matter } \\
\text { - Slow acting against nonenveloped viruses (eg, norovirus) } \\
\text { - No detergent or cleaning properties } \\
\text { - Not EPA registered } \\
\text { - Damage to some instruments (eg, hardens rubber, } \\
\text { deteriorates glue) } \\
\text { - Flammable (large amounts require special storage) } \\
\text { - Evaporates rapidly, making contact time compliance } \\
\text { difficult } \\
\text { - Not recommended for use on large surfaces } \\
\text { - Outbreaks ascribed to contaminated alcohol }{ }^{24}\end{array}$ \\
\hline Sodium hypochlorite & $\begin{array}{l}\text { - } \text { Bactericidal, tuberculocidal, fungicidal, virucidal } \\
\text { - } \text { Sporicidal } \\
\text { - Fast-acting } \\
\text { - Inexpensive (in dilutable form) } \\
\text { - Not flammable } \\
\text { - Unaffected by water hardness } \\
\text { - Reduces biofilms on surfaces } \\
\text { - Relatively stable (eg, } 50 \% \text { reduction in chlorine } \\
\text { - Uncentration in } 30 \mathrm{~d})^{25} \\
\text { - EPA registered }\end{array}$ & $\begin{array}{l}\text { - Reaction hazard with acids and ammonias } \\
\text { - Leaves salt residue } \\
\text { - Corrosive to metals (some ready-to-use products may be } \\
\text { formulated with corrosion inhibitors) } \\
\text { - Unstable active (some ready-to-use products may be } \\
\text { formulated with stabilizers to achieve longer shelf life) } \\
\text { - Affected by organic matter } \\
\text { - Discolors and stains fabrics } \\
\text { - Potential hazard is production of trihalomethane } \\
\text { - Odor (some ready-to-use products may be formulated } \\
\text { with odor inhibitors); irritating at high concentrations }\end{array}$ \\
\hline $\begin{array}{l}\text { Improved hydrogen } \\
\text { peroxide }\end{array}$ & $\begin{array}{l}\text { - Bactericidal, tuberculocidal, fungicidal, virucidal } \\
\text { - Fast efficacy } \\
\text { - Easy compliance with wet-contact times } \\
\text { - Safe for workers (lowest EPA toxicity category, IV) } \\
\text { - Benign for the environment } \\
\text { - Surface compatible } \\
\text { - Nonstaining } \\
\text { - EPA registered } \\
\text { - Not flammable }\end{array}$ & $\begin{array}{l}\text { - More expensive than most other disinfecting actives } \\
\text { - Not sporicidal at low concentrations }\end{array}$ \\
\hline Iodophors & $\begin{array}{l}\text { - Bactericidal, mycobactericidal, virucidal } \\
\text { - Not flammable } \\
\text { - Used for disinfecting blood culture bottles }\end{array}$ & $\begin{array}{l}\text { - Not sporicidal } \\
\text { - Shown to degrade silicone catheters } \\
\text { - Requires prolonged contact to kill fungi } \\
\text { - Stains surfaces } \\
\text { - Used mainly as an antiseptic rather than disinfectant }\end{array}$ \\
\hline Phenolics & $\begin{array}{l}\text { - Bactericidal, tuberculocidal, fungicidal, virucidal } \\
\text { - Inexpensive (in dilutable form) } \\
\text { - Nonstaining } \\
\text { - Not flammable } \\
\text { - EPA registered }\end{array}$ & $\begin{array}{l}\text { - Not sporicidal } \\
\text { - Absorbed by porous materials and irritate tissue } \\
\text { - Depigmentation of skin caused by certain phenolics } \\
\text { - Hyperbilirubinemia in infants when phenolic not prepared } \\
\text { as recommended }\end{array}$ \\
\hline $\begin{array}{l}\text { Quaternary } \\
\text { ammonium } \\
\text { compounds (eg, } \\
\text { didecyl dimethyl } \\
\text { ammonium bromide, } \\
\text { dioctyl dimethyl } \\
\text { ammonium bromide) }\end{array}$ & $\begin{array}{l}\text { - Bactericidal, fungicidal, virucidal against enveloped viruses } \\
\text { (eg, HIV) } \\
\text { - Good cleaning agents } \\
\text { - EPA registered } \\
\text { - Surface compatible } \\
\text { - Persistent antimicrobial activity when undisturbed } \\
\text { - Inexpensive (in dilutable form) }\end{array}$ & $\begin{array}{l}\text { - Not sporicidal } \\
\text { - In general, not tuberculocidal and virucidal against } \\
\text { nonenveloped viruses } \\
\text { - High water hardness and cotton-gauze can make less } \\
\text { microbicidal } \\
\text { - A few reports documented asthma as result of exposure to } \\
\text { benzalkonium chloride } \\
\text { - Affected by organic matter } \\
\text { - Multiple outbreaks ascribed to contaminated } \\
\text { benzalkonium chloride }\end{array}$ \\
\hline $\begin{array}{l}\text { Peracetic acid and } \\
\text { hydrogen peroxide }\end{array}$ & $\begin{array}{l}\text { - Bactericidal, fungicidal, virucidal and sporicidal (eg, } \\
\text { Clostridium difficile) } \\
\text { - Active in the presence of organic material } \\
\text { - Environmental friendly by-products (acetic acid, } \mathrm{O}_{2}, \mathrm{H}_{2} 0 \text { ) } \\
\text { - EPA registered } \\
\text { - Surface compatible }\end{array}$ & $\begin{array}{l}\text { - Lack of stability } \\
\text { - Potential to material incompatibility (eg, brass, copper) } \\
\text { - More expensive than other disinfecting actives } \\
\text { - Odor }\end{array}$ \\
\hline
\end{tabular}

NOTE. Modified with permission from Rutala and Weber. ${ }^{10}$

Abbreviation: EPA, Environmental Protection Agency.

markers, and adenosine triphosphate (ATP) assays. At present, polymerase chain reaction-based technology has a limited role for assessing environmental contamination, is investigational, and does not differentiate between the presence of viable and nonviable microorganisms. ${ }^{13}$

Hospital cleanliness continues to attract patient attention, and in the United States it is still primarily assessed via visual cleanliness (eg, dust, organic debris) of surfaces, which is not a reliable indicator of microbial contamination. ${ }^{34,35}$ ATP bioluminescence measures organic debris (each unit has its own reading scale, $<250$ -
500 relative light units), but it is not a reliable indicator of microbial contamination. ${ }^{13}$ A validation study of ATP used to audit cleaning of flexible endoscope channels demonstrated that an endoscope assessed as clean by ATP ( $<250$ relative light units) could be contaminated with a million $\left(10^{6}\right)$ microorganisms. ${ }^{36}$ Fluorescent marking is done with a transparent, easily cleaned, environmentally stable marking solution that fluoresces when exposed to an ultraviolet (UV) light. It is applied by the infection preventionist or environmental service manager after the patient is discharged and is unknown to the environmental service staff. After 
Table 3

Most prevalent pathogens causing HAIs

\begin{tabular}{|c|c|}
\hline Recommended organisms (\% of HAIs caused) & Why organisms are relevant \\
\hline $\begin{array}{l}\text { Staphylococcus aureus (15.6\%) } \\
\text { Escherichia coli (11.5\%) } \\
\text { Coagulase-negative Staphylococcus (11.4\%) } \\
\text { Klebsiella (8.0\%) } \\
\text { Pseudomonas aeruginosa (7.5\%) } \\
\text { Enterococcus faecalis }(6.8 \%) \\
\text { Candida albicans }(5.3 \%) \\
\text { Enterobacter spp (4.7\%) } \\
\text { Other Candida spp (4.2\%) } \\
\text { Enterococcus faecium }(4.1 \%) \\
\text { Enterococcus spp (3.0\%) } \\
\text { Proteus spp (2.5\%) } \\
\text { Serratia spp (2.1\%) } \\
\text { Acinetobacter baumannii (1.8\%) } \\
\text { Clostridium difficile spores* }\end{array}$ & $\begin{array}{l}\text { Most prevalent overall } \\
\text { contributors to HAIs } \\
(\mathrm{NHSN}-\mathrm{CDC})^{26}\end{array}$ \\
\hline $\begin{array}{l}\text { Norovirus } \\
\text { Aspergillus } \\
\text { Rotavirus } \\
\text { Adenovirus } \\
\text { (Insert facility-specific pathogens here } \\
\quad \text { [eg, Burkholderia cepacia]) }\end{array}$ & $\begin{array}{l}\text { Most common causes of } \\
\text { outbreaks and ward closures } \\
\text { by causative pathogen, which } \\
\text { are relatively hard to kill }{ }^{27} \\
\text { Other pathogens of concern in } \\
\text { your facility }\end{array}$ \\
\hline
\end{tabular}

NOTE. Modified from Rutala and Weber. ${ }^{10}$

Abbreviations: $C D C$, Centers for Disease Control and Prevention; HAI, health careassociated infection; NHSN, National Healthcare Safety Network.

*Over the last decade, an increasing incidence of $C$ difficile has been recognized, and in many health care facilities it is the most common cause of HAI.

environmental service cleaning, the markings are reassessed by the infection preventionist or environmental service manager, thoroughness of the cleaning is monitored, and immediate feedback is provided to the person(s) cleaning-disinfecting the room (eg, 4 of 10 marker surfaces wiped, $40 \%$ compliance with thoroughness of cleaning-disinfection). Microbiologic methods have also been used to evaluate microbial contamination of surfaces. This method can be costly and pathogenic specific. Although there are no accepted criteria for defining a surface as clean using microbiologic methods, some investigators have suggested that microbial contamination should be 2.5 to $<5$ colony forming units $(\mathrm{CFU}) / \mathrm{cm}^{2}{ }^{37,38}$ Studies have shown that this level of contamination may be easily achievable because the microbial burden of room surfaces in 1 hospital went from $57 \mathrm{CFU} /$ Rodac (replicate organism detection and counting) $\left(2.3 \mathrm{CFU} / \mathrm{cm}^{2}\right)$ to $8 \mathrm{CFU} /$ Rodac $\left(0.3 \mathrm{CFU} / \mathrm{cm}^{2}\right)$ prior to and after cleaning. ${ }^{39}$ Based on surface cleaning-disinfection practices that are used in the United States, a revised stricter pass benchmark may need to be considered $\left(<1 \mathrm{CFU} / \mathrm{cm}^{2}\right)$.

Studies have demonstrated suboptimal cleaning by aerobic colony counts and the use of the ATP bioluminescence and fluorescent markers. ${ }^{6,35}$ For example, Carling et al assessed the thoroughness of terminal cleaning in the patient's immediate environment in 23 acute care hospitals ( 1,119 patient rooms) by using a transparent, stable solution that fluoresces when exposed to handheld UV light. ${ }^{40}$ The overall thoroughness of cleaning, expressed as a percent of surfaces evaluated, was $49 \%$ (range for all hospitals, 35\%-81\%). Using a similar design, Carling et al assessed the environmental cleaning in intensive care unit rooms in 16 hospitals (2,320 objects) and demonstrated that only $57.1 \%$ of sites were cleaned after discharge of the room's occupant. ${ }^{41}$ A study using ATP bioluminescence assays and aerobic cultures demonstrated that medical equipment frequently had not been disinfected as per protocol. ${ }^{42}$

ATP bioluminescence and fluorescent markers are preferred to aerobic plate counts because they provide an immediate assessment of cleaning effectiveness. Two recent reviews reported ATP as a quick and objective monitoring method; however, it was poorly standardized with low specificity and sensitivity in detecting bacteria. ${ }^{13,43,44}$ In a comparison study of the 4 methods to assess cleaning, we found that the fluorescent marker was the most useful tool in determining how thoroughly a surface was wiped because it mimicked the microbiologic data better than ATP. For example, compared with microbiologic data (when $<62.5$ CFU/Rodac defines clean), $72 \%$ were classified as clean with fluorescent markers, compared with $27 \%$ were classified as clean compared with ATP (Rutala et al, unpublished results, 2015).

\section{SURFACE DISINFECTION, CONTACT TIME, WIPES AND WIPE METHOD}

Surface disinfection of noncritical surfaces and equipment is normally performed by manually applying a liquid disinfectant to the surface with a wipe or mop. Noncritical patient care equipment is disinfected using an EPA-registered hospital disinfectant using the label's safety precautions and use directions (Table 2). Many diluted EPA-registered hospital disinfectants have a label contact time of 10 minutes (eg, quaternary ammonium compound). However, multiple scientific studies have demonstrated the efficacy of hospital disinfectants against pathogens with a contact time of at least 1 minute. ${ }^{10,29}$ Health care facilities should ensure that the frequency for disinfecting noncritical patient care surfaces be done minimally when visibly soiled and on a regular basis (eg, after use on each patient or once daily or once weekly). ${ }^{29}$ Data indicate that daily disinfection of high-touch surfaces, compared with disinfecting when soiled, reduces the acquisition of pathogens on hands after contact with surfaces and the mean number of bacteria acquired. ${ }^{30}$ For example, a hospital's policy for reusable blood pressure cuffs kept in the patient room could be that they are cleaned when visibly soiled and at discharge before use for another patient. Similarly, for rolling blood pressure cuffs, the policy could be they are cleaned daily and when visibly soiled, when used on a contact precaution patient, and when used on nonintact skin. If dedicated, disposable equipment is not available, disinfect noncritical patient care equipment after using it on a patient who is on contact precautions before using this equipment on another patient.

The wipes used for surface disinfection are generally cotton, cellulose-based, nonwoven spunlace, and microfiber. The disinfectants are usually applied with a spray (ie, spray-and-wipe procedure), wipes (eg, cotton, microfiber) soaked in a disinfectant-filled bucket, or a premoistened wipe (eg, disposable wipe). All of these methods combine the antimicrobial action of the disinfectant with the physical removal of microorganisms by wiping. The efficacy of the wipe method has been recently evaluated using $C$ difficile spores. The wipe methods (ie, saturated cloth; spray [let disinfectant sit for 10 seconds] and wipe; spray, wipe, spray [let disinfectant sit for 1 minute], and wipe; disposable wipe; spray, wipe, spray, and let air dry) all demonstrated similar reductions in $C$ difficile spores using a disinfectant active against $C$ difficile spores. ${ }^{22}$ The wipe should have sufficient wetness to achieve the disinfectant contact time. Discard the wipe if it no longer leaves the surface visibly wet for $\geq 1$ minute. Other practices to consider include the following: when the wipe is visibly soiled, flip to a clean-unused side and continue until all sides of the wipe have been used (or get another wipe); dispose of the wipe or cloth wipe appropriately; do not place the cleaning cloth back into the disinfectant solution after using it to wipe a surface; and do not dip a used wipe into the clean container of presaturated wipes. If a disposable wipe is used, ideally the wipe should keep the surface wet long enough to meet EPA-registered contact times (eg, bacteria: 1 minute). For disposable wipes, the premoistened wipe should keep the surface area wet for 1-2 minutes, and the surface coverage will depend on the size of the wipe (eg, 12- $\times 12$-in wipes keep $5.156 \mathrm{sq} \mathrm{m}$ wet for 2 minutes; $6-\times 5$-in equipment wipe keeps 0.622 sq $\mathrm{m}$ wet for 2 minutes). The disposable wipe size should be based on use from small surfaces (eg, blood pressure cuff) to large 
surfaces (eg, mattress covers). Additionally, the substrate for the disposable wipe should be durable so that it does not easily tear or fall apart, and the top should be kept closed so the wipes do not dry out. Change the reusable cleaning cloths after every room and use at least 3 cloths per room..$^{10,45}$ Boyce et al also found that smooth surfaces (eg, overbed tables) were cleaned more thoroughly (as measured by ATP) than rough or irregular surfaces, and the rooms cleaned with only 2 disinfectant wipes had higher ATP readings than those cleaned with 3,4 , or 5 wipes. ${ }^{46}$ If the reusable wipe is not changed, accumulation of bacteria can occur and increase the chance of cross-contamination.

In addition, the antimicrobial activity of some disinfectants will be affected by certain fabrics or cloths. Quaternary ammonium compounds interact with cotton and microfiber cloths via electrostatic attractions, resulting in lower concentrations of the active ingredient delivered to the surface. For example, cotton rags or disposable cellulose-based wipes with quaternary ammonium compounds may release lower amounts of active quaternary ammonium compounds ( $\geq 30 \%$ lower) than nonwoven spunlace wipes than is indicated by testing the solution ${ }^{47}$ Engelbrecht et al found that the quaternary ammonium compound concentration was reduced by up to $85 \%$ after exposure to cotton towels. ${ }^{48}$ Even though cotton and microfiber retain the quaternary ammonium compound, 1 study has shown they provide equivalent removal-inactivation of MRSA from a surface as nonwoven spunlace wipes (eg, $4.41 \log _{10}$ reduction with cotton and QUAT (a quaternary ammonium compound), $4.60 \log _{10}$ reduction with spunlace, $4.51 \log _{10}$ reduction with microfiber, 4.40 $\log _{10}$ reduction with cellulose; Rutala et al, unpublished results, 2013). Additional investigations are necessary to ensure a minimum effective concentration is present to achieve the antimicrobial label claim.

An issue that has been receiving repeated attention in the media is the contact times for disposable wipes when there are varying times listed for bacteria, fungi, and mycobacteria. Some persons have suggested that hospitals should use the longest kill time on the product as the required wet-contact kill time (eg, 5 minutes for $M y$ cobacterium bovis). The CDC's "Guideline for Disinfection and Sterilization in Healthcare Facilities" used the time necessary to kill bacteria on surfaces (ie, 1 minute), not the kill time for more difficult to inactivate pathogens, such as $M$ tuberculosis or $M$ bovis, which does not have an environmental surface mode of transmission. ${ }^{29}$ Because bacteria (with the exception of $C$ difficile spores) to include multidrug-resistant bacteria (eg, MRSA, VRE) cause approximately $80 \%$ of HAIs and removal or inactivation of bacteria on surfaces is important in preventing environmentally mediated HAIs, bacterial kill times should dictate the wet-contact kill times in health care facilities. Therefore, for low-level disinfectant products used on noncritical environmental surfaces or noncritical medical instruments, the recommended wet-contact kill times would be $\geq 1$ minute.

\section{IMPROVING ROOM CLEANING AND DISINFECTION AND DEMONSTRATING THE EFFECTIVENESS OF SURFACE DECONTAMINATION IN REDUCING HAIS}

Investigators have reported that intervention programs aimed at improving surface cleaning and disinfection reduced HAIs. ${ }^{18}$ Such interventions have generally included multiple activities: disinfectant product substitutions and interventions to improve the effectiveness of cleaning and disinfection (eg, improved housekeeper education, monitoring the thoroughness of cleaning [eg, by use of ATP assays or fluorescent dyes] with feedback of performance to the environmental service workers, use of cleaning checklists). ${ }^{18,49-51}$ Health care facilities must also allow adequate time for room processing to ensure adherence to all steps recommended by institutional policies and professional organization guidelines. We have found that collaboration between infection prevention and environmental services staff and management is critical to an effective environmental cleaning program. This includes ensuring that environmental services staff recognize the importance of their job and the relationship of adhering to proper work procedures to the reduction of microbial contamination and HAIs. The assignment of cleaning responsibility (eg, medical equipment to be cleaned by nursing; environmental surfaces to be cleaned by environmental services) is also important to ensure all objects and surfaces in a patient room are decontaminated, especially the surfaces of medical equipment (eg, cardiac monitors). Improved environmental cleaning has been demonstrated to reduce the environmental contamination with VRE, ${ }^{51}$ MRSA, ${ }^{52}$ and $C$ difficile. ${ }^{53}$ Further, all studies have only focused improvement on a limited number of high-risk objects. Therefore, a concern of published studies is that they have only demonstrated improved cleaning of a limited number of high-risk objects (or targeted objects), not an improvement in the overall thoroughness of room decontamination, which is the objective.

To our knowledge only 1 study has objectively evaluated what constitutes high-touch objects in a patient room, and no study has demonstrated epidemiologically what constitutes a high-risk object. Examples of what the literature refers to as high-touch objects include bed rails, intravenous poles, call buttons, door knobs, floors, and bathroom facilities, ${ }^{13}$ but a study demonstrated high-touch objects in the intensive care unit were the bed rail, bed surface, and supply cart, whereas the high-touch surfaces in a patient ward were the bed rail, over-the-bed table, intravenous pump, and bed surface. ${ }^{54}$ Importantly, the level of microbial contamination of room surfaces was statistically similar regardless of how often they were touched before and after cleaning. Until research identifies which objects and surfaces pose the greatest risk of pathogen transmission, all noncritical surfaces that are touched must be cleaned-disinfected. ${ }^{39}$

\section{NO-TOUCH (OR MECHANICAL) METHODS FOR ROOM DECONTAMINATION}

As previously noted, multiple studies have demonstrated that environmental surfaces and objects in rooms are frequently not properly cleaned, and these surfaces may be important in transmission of health care-associated pathogens. Further, although interventions aimed at improving cleaning thoroughness have demonstrated effectiveness, many surfaces remain inadequately cleaned and therefore potentially contaminated. For this reason, several manufacturers have developed room disinfection units that can decontaminate environmental surfaces and objects. These no-touch systems generally use 1 of 2 methods: UV light or HP vapor-mist. ${ }^{4}$ These technologies supplement, but do not replace, standard cleaning and disinfection because surfaces must be physically cleaned of dirt and debris.

\section{UV light for room decontamination}

UV radiation has been used for the control of pathogenic microorganisms in a variety of applications, such as control of legionellosis, and the disinfection of air, surfaces, and instruments. ${ }^{4,55}$ At certain wavelengths, UV light will break the molecular bonds in DNA, thereby destroying the organism. UV radiation has peak germicidal effectiveness in the wavelength range of $240-280 \mathrm{~nm}$. Mercury gas bulbs emit UV-C at $254 \mathrm{~nm}$, whereas xenon gas bulbs produce a broad spectrum of radiation that encompasses the UV $(100-280 \mathrm{~nm})$ and the visible $(380-700 \mathrm{~nm})$ electromagnetic spectra. ${ }^{56}$ The efficacy of UV radiation is a function of many different parameters, such as dose, distance, direct or shaded exposure, exposure time, lamp placement, pathogen, carrier or surface tested, 
inoculum method, organic load, and orientation of carriers (eg, parallel vs perpendicular). Data demonstrate that several UV systems have effectiveness (eg, eliminate $>3 \log _{10}$ vegetative bacteria [MRSA, VRE, $A$ baumannii] and $>2.4 \log _{10} C$ difficile) at relatively short exposure times (eg, 5-25 minutes for bacteria, 10-60 minutes for $C$ difficile spores). ${ }^{56-58}$ The studies also demonstrated reduced effectiveness when surfaces were not in direct line of sight. ${ }^{56-60}$

\section{HP systems for room decontamination}

Several systems which produce HP (eg, HP vapor, aerosolized dry mist HP) have been studied for their ability to decontaminate environmental surfaces and objects in hospital rooms. HP vapor has been used increasingly for the decontamination of rooms in health care. ${ }^{61-71}$ These investigators found that HP systems are a highly effective method for eradicating various pathogens (eg, MRSA, $M$ tuberculosis, Serratia, $C$ difficile spores, $C$ botulinum spores) from rooms, furniture, and equipment.

\section{Comparison of UV irradiation vs HP for room decontamination}

The UV and HP systems have their own advantages and disadvantages, ${ }^{4}$ and there is now ample evidence that these notouch systems can reduce environmental contamination with health care-associated pathogens. However, each specific system should be studied and its efficacy demonstrated before being introduced into health care facilities. The main advantage of both types of units is their ability to achieve substantial reductions in vegetative bacteria. Another advantage is their ability to substantially reduce $C$ difficile spores because low-level disinfectants (eg, quaternary ammonium compounds) have only limited or no measurable activity against spore-forming bacteria. ${ }^{10}$ Both systems are residual free, and they decontaminate all exposed surfaces and equipment in the room.

The major disadvantages of both decontamination systems are the substantial capital equipment costs, the need to remove personnel and patients from the room therefore limiting their use to terminal room disinfection (must prevent or minimize exposure to UV and HP), the staff time needed to transport the system to rooms to be decontaminated and monitor its use, the need to physically clean the room of dust and debris, and the sensitivity to use parameters. There are several important differences between the 2 systems. The UV-C systems offer faster decontamination, which reduces the down time of the room before another patient can be admitted. The HP systems have been demonstrated to be more effective in eliminating spore-forming organisms. Whether this improved sporicidal activity is clinically important is unclear because studies have demonstrated that although environmental contamination is common in the rooms of patients with C difficile infection, the level of contamination is relatively low (also true for MRSA and VRE). Importantly, the HP and UV systems were demonstrated to reduce the incidence of HAIs. ${ }^{61,72-75}$ Based on data that demonstrated a reduction of colonizations and infections associated with these technologies, we recommend they be used for terminal room decontamination after discharge of patients on contact precautions. Because different UV and HP systems vary substantially, infection preventionists should review the peer-reviewed literature and choose only devices with demonstrated bactericidal capability as assessed by carrier tests or the ability to disinfect actual patient rooms. Ultimately, one would select a device that has demonstrated the ability to reduce HAIs. ${ }^{75}$

\section{FUTURE DIRECTIONS FOR NO-TOUCH TECHNOLOGIES}

Novel technologies have dramatically improved the likelihood of developing a self-disinfecting surface or a continuous room dis- infection strategy. These strategies include the development of selfdisinfecting surfaces, such as surfaces impregnated or coated with a heavy metal (eg, silver, copper) or a germicide (eg, quaternary ammonium compounds). ${ }^{76-78}$ The use of such technology could minimize the impact of poor cleaning and disinfecting practices during routine and terminal room cleaning and disinfection. Other novel methods for room disinfection are being investigated. For example, visible light disinfection through light-emitting diodes can be applied continuously to environments to provide microbial reductions even while the environments are occupied. The light-emitting diodes release a wavelength of light that is antimicrobial $(405 \mathrm{~nm})$ and not hazardous to patients and staff. ${ }^{79}$ Another potential method for continuous room decontamination uses continuous low-dose HP (eg, 0.5 ppm HP vapor).

\section{CONCLUSION}

Environmental contamination plays an important role in the transmission of several epidemiologically important pathogens, such as MRSA, VRE, and $C$ difficile. Disinfection should render surfaces and equipment free of pathogens in sufficient numbers to cause human disease (ie, hygienically clean). This requires thorough cleaning-disinfecting of the patient environment using effective products and processes and no-touch technologies that reduce the incidence of HAIs.

\section{References}

1. Otter JA, Yezli S, French GL. The role played by contaminated surfaces in the transmission of nosocomial pathogens. Infect Control Hosp Epidemiol 2011;32:687-99.

2. Boyce JM. Environmental contamination makes an important contribution to hospital infection. J Hosp Infect 2007;65(Suppl):50-4.

3. Weber DJ, Anderson DJ, Sexton DJ, Rutala WA. Role of the environment in the transmission of Clostridium difficile in health care facilities. Am J Infect Control 2013;41(Suppl):S105-10.

4. Rutala WA, Weber DJ. Disinfectants used for environmental disinfection and new room decontamination technology. Am J Infect Control 2013;41(Suppl):S36-41.

5. Stiefel U, Cadnum JL, Eckstein BC, Guerrero DM, Tima MA, Donskey CJ Contamination of hands with methicillin-resistant Staphylococcus aureus after contact with environmental surfaces and after contact with the skin of colonized patients. Infect Control Hosp Epidemiol 2011;32:185-7.

6. Carling P. Methods for assessing the adequacy of practice and improving room disinfection. Am J Infect Control 2013;41(Suppl):S20-5

7. Huang SS, Datta R, Platt R. Risk of acquiring antibiotic-resistant bacteria from prior room occupants. Arch Intern Med 2006;166:1945-51.

8. Shaughnessy MK, Micielli RL, DePestel DD, Arndt J, Strachan CL, Welch KB, et al. Evaluation of hospital room assignment and acquisition of Clostridium difficile infection. Infect Control Hosp Epidemiol 2011;32:201-6.

9. Rutala WA, Weber DJ. Disinfection, sterilization and control of hospital waste. In: Bennett JE, Dolin R, Blaser MJ, editors. Principles and practice of infectious diseases. Philadelphia (PA): Elsevier Saunders; 2015:3294-309.

10. Rutala WA, Weber DJ. Selection of the ideal disinfectant. Infect Control Hosp Epidemiol 2014;35:855-65.

11. Rutala WA, Gergen MF, Sickbert-Bennett EE, Williams DA, Weber DJ. Effectiveness of improved hydrogen peroxide in decontaminating privacy curtains contaminated with multidrug-resistant pathogens. Am J Infect Control 2014;42:426-8.

12. Han JH, Sullivan N, Leas BF, Pegues DA, Kaczmarek JL, Umscheid CA. Cleaning hospital room surfaces to prevent health care-associated infections. Ann Intern Med 2015;163:598-607.

13. Leas BF, Sullivan N, Han JH, Pegues DA, Kaczmarek JL, Umscheid CA. Environmental cleaning for the prevention of healthcare-associated infection. Technical Brief No. 22 (prepared by the ECRI Institute-Penn Agency for Healthcare Research and Quality. 2015. Available from: http://www .effectivehealthcare.ahrq.gov/ehc/products/592/2103/healthcare-infectionsreport-150810.pdf. Accessed December 29, 2015.

14. Wenzel RP, Edmond MB. Infection control: the case for horizontal rather than vertical interventional programs. Int J Infect Dis 2010;14(Suppl):S3-5.

15. How to select an ideal disinfectant. Infection Control Today. 2009. Available from: http://www.infectioncontroltoday.com/articles/2009/05/how-to-select-anideal-disinfectant.aspx. Accessed December 29, 2015.

16. Otter JA, Yezli S, Salkeld JA, French GL. Evidence that contaminated surfaces contribute to the transmission of hospital pathogens and an overview of strategies to address contaminated surfaces in hospital settings. Am J Infect Control 2013;41(Suppl):S6-11. 
17. Molinari JA, Gleason MJ, Cottone JA, Barrett ED. Comparison of dental surface disinfectants. Gen Dent 1987;35:171-5.

18. Donskey CJ. Does improving surface cleaning and disinfection reduce health care-associated infections? Am J Infect Control 2013;41(Suppl):S12-9.

19. Rutala WA, Weber DJ. The benefits of surface disinfection. Am J Infect Control 2005;33:434-5.

20. Alfa MJ, Lo E, Olson N, MacRae M, Buelow-Smith L. Use of a daily disinfectant cleaner instead of a daily cleaner reduced hospital-acquired infection rates. Am J Infect Control 2015;43:141-6.

21. Ramm L, Siani H, Wesgate R, Maillard JY. Pathogen transfer and high variability in pathogen removal by detergent wipes. Am J Infect Control 2015;43:724-8.

22. Rutala WA, Gergen MF, Weber DJ. Efficacy of different cleaning and disinfection methods against Clostridium difficile spores: importance of physical removal versus sporicidal inactivation. Infect Control Hosp Epidemiol 2012;33:1255-8.

23. Cadnum JL, Hurless KN, Kundrapu S, Donskey CJ. Transfer of Clostridium difficile spores by nonsporicidal wipes and improperly used hypochlorite wipes: practice + product $=$ perfection. Infect Control Hosp Epidemiol 2013;34:441-2.

24. Weber DJ, Rutala WA, Sickbert-Bennett EE. Outbreaks associated with contaminated antiseptics and disinfectants. Antimicrob Agents Chemother 2007;51:4217-24.

25. Rutala WA, Cole EC, Thomann CA, Weber DJ. Stability and bactericidal activity of chlorine solutions. Infect Control Hosp Epidemiol 1998;19:323-7.

26. Sievert DM, Ricks P, Edwards JR, Schneider A, Patel J, Srinivasan A, et al. Antimicrobial-resistant pathogens associated with healthcare-associated infections: summary of data reported to the National Healthcare Safety Network at the Centers for Disease Control and Prevention, 2009-2010. Infect Control Hosp Epidemiol 2013;34:1-14.

27. Hansen S, Stamm-Balderjahn S, Zuschneid I, Behnke M, Ruden J, Vonberg RP, et al. Closure of medical departments during nosocomial outbreaks: data from a systematic analysis of the literature. J Hosp Infect 2007;2007:348-53.

28. Kang J, Sickbert-Bennett EE, Brown VM, Weber DJ, Rutala WA. Relative frequency of health care-associated pathogens by infection site at a university hospital from 1980 to 2008. Am J Infect Control 2012;40:416-20.

29. Rutala WA, Weber DJ, Healthcare Infection Control Practices Advisory Committee (HICPAC). Guideline for disinfection and sterilization in healthcare facilities, 2008 Available from: http://www.cdc.gov/ncidod/dhqp/pdf/guidelines/ Disinfection_Nov_2008.pdf. Accessed December 29, 2015.

30. Kundrapu S, Sunkesula V, Jury LA, Sitzlar BM, Donskey CJ. Daily disinfection of high-touch surfaces in isolation rooms to reduce contamination of healthcare workers' hands. Infect Control Hosp Epidemiol 2012;33:1039-42.

31. Rutala WA, Gergen MF, Weber DJ. Efficacy of improved hydrogen peroxide against important healthcare-associated pathogens. Infect Control Hosp Epidemiol 2012;33:1159-61.

32. Deshpande A, Mana TS, Cadnum JL, Jencson AC, Sitzlar B, Fertelli D, et al. Evaluation of a sporicidal peracetic acid/hydrogen peroxide-based daily disinfectant cleaner. Infect Control Hosp Epidemiol 2014;35:1414-6.

33. Carling PC, Perkins J, Ferguson J, Thomasser A. Evaluating a new paradigm for comparing surface disinfection in clinical practice. Infect Control Hosp Epidemiol 2014;35:1349-55.

34. Cooper RA, Griffith CJ, Malik RE, Obee P, Looker N. Monitoring the effectiveness of cleaning in four British hospitals. Am J Infect Control 2007;35:338-41.

35. Guh A, Carling P. Options for evaluating environmental cleaning. 2010. Available from: http://www.cdc.gov/HAI/pdfs/toolkits/Environ-Cleaning-Eval-Toolkit122-2010.pdf. Accessed December 29, 2015.

36. Alfa MJ, Fatima I, Olson N. Validation of adenosine triphosphate to audit manual cleaning of flexible endoscope channels. Am J Infect Control 2013;41:245-8.

37. Dancer SJ. How do we assess hospital cleaning? A proposal for microbiological standards for surface hygiene in hospitals. J Hosp Infect 2004;56:10-5.

38. Lewis T, Griffith C, Gallo M, Weinbren M. A modified ATP benchmark for evaluating the cleaning of some hospital environmental surfaces. J Hosp Infect 2008:69:156-63.

39. Huslage K, Rutala WA, Gergen MF, Sickbert-Bennett EE, Weber DJ. Microbial assessment of high-, medium-, and low-touch hospital room surfaces. Infect Control Hosp Epidemiol 2013;34:211-2.

40. Carling PC, Parry MF, Von Beheren SM, Healthcare Environmental Hygiene Study Group. Identifying opportunities to enhance environmental cleaning in 23 acute care hospitals. Infect Control Hosp Epidemiol 2008;29:1-7.

41. Carling PC, Von Beheren S, Kim P, Woods C, Healthcare Environmental Hygiene Study Group. Intensive care unit environmental cleaning: an evaluation in sixteen hospitals using a novel assessment tool. J Hosp Infect 2008;68:39-44.

42. Havill NL, Havill HL, Mangione E, Dumigan DG, Boyce JM. Cleanliness of portable medical equipment disinfected by nursing staff. Am J Infect Control 2011;39:6024.

43. Amodio E, Dino C. Use of ATP bioluminescence for assessing the cleanliness of hospital surfaces: a review of the published literature (1990-2012). J Infect Public Health 2014;7:92-8.

44. Mitchell BGWF, Dancer SJ, Dancer SJ, McGregor A. Methods to evaluate environmental cleanliness in healthcare facilities. Healthc Infect 2013;18:23-30.

45. Hota B, Blom DW, Lyle EA, Weinstein RA, Hayden MK. Interventional evaluation of environmental contamination by vancomycin-resistant enterococci: failure of personnel, product, or procedure? J Hosp Infect 2009;71:123-31.

46. Boyce JM, Havill NL, Lipka A, Havill H, Rizvani R. Variations in hospital daily cleaning practices. Infect Control Hosp Epidemiol 2010;31:99-101.

47. MacDougall KD, Morris C. Optimizing disinfectant application in healthcare facilities. Infect Control Today 2006; June:62-7.
48. Engelbrecht K, Ambrose D, Sifuentes L, Gerba C, Weart I, Koenig D. Decreased activity of commercially available disinfectants containing quaternary ammonium compounds when exposed to cotton towels. Am J Infect Control 2013;41:908-11.

49. Carling PC, Bartley JM. Evaluating hygienic cleaning in health care settings: what you do not know can harm your patients. Am J Infect Control 2010; 38(Suppl):S41-50.

50. Boyce JM, Havill NL, Dumigan DG, Golebiewski M, Balogun O, Rizvani R. Monitoring the effectiveness of hospital cleaning practices by use of an adenosine triphosphate bioluminescence assay. Infect Control Hosp Epidemiol 2009;30:678-84

51. Hota B, Blom DW, Lyle EA, Weinstein RA, Hayden MK. Interventional evaluation of environmental contamination by vancomycin-resistant enterococci: failure of personnel, product or procedure? J Hosp Infect 2009;71:123-31.

52. Goodman ER, Platt R, Bass R, Onderdonk AB, Yokoe DS, Huang SS. Impact of an environmental cleaning intervention on the presence of methicillin-resistant Staphylococcus aureus and vancomycin-resistant enterococci on surfaces in intensive care unit rooms. Infect Control Hosp Epidemiol 2008;29:593-9.

53. Eckstein BC, Adams DA, Eckstein EC, Rao A, Sethi AK, Yadavalli GK, et al. Reduction of Clostridium difficile and vancomycin-resistant Enterococcus contamination of environmental surfaces after an intervention to improve cleaning methods. BMC Infect Dis 2007;7:61.

54. Huslage K, Rutala WA, Sickbert-Bennett E, Weber DJ. A quantitative approach to defining "high-touch" surfaces in hospitals. Infect Control Hosp Epidemiol 2010;31:850-3.

55. Memarzadeh F, Olmsted RN, Bartley JM. Applications of ultraviolet germicidal irradiation disinfection in health care facilities: effective adjunct, but not stand-alone technology. Am J Infect Control 2010;38(Suppl):S13-24.

56. Nerandzic MM, Thota P, Sankar CT, Jencson A, Cadnum JL, Ray AJ, et al. Evaluation of a pulsed xenon ultraviolet disinfection system for reduction of healthcareassociated pathogens in hospital rooms. Infect Control Hosp Epidemiol 2015;36:192-7.

57. Rutala WA, Gergen MF, Weber DJ. Room decontamination with UV radiation. Infect Control Hosp Epidemiol 2010;31:1025-9.

58. Rutala WA, Gergen MF, Tande BM, Weber DJ. Room decontamination using an ultraviolet-C device with short ultraviolet exposure time. Infect Control Hosp Epidemiol 2014;35:1070-2.

59. Nerandzic MM, Cadnum JL, Pultz MJ, Donskey CJ. Evaluation of an automated ultraviolet radiation device for decontamination of Clostridium difficile and other healthcare-associated pathogens in hospital rooms. BMC Infect Dis 2010;10:197.

60. Boyce JM, Havill NL, Moore BA. Terminal decontamination of patient rooms using an automated mobile UV light unit. Infect Control Hosp Epidemiol 2011;32:73742.

61. Boyce JM, Havill NL, Otter JA, McDonald LC, Adams NM, Cooper T, et al. Impact of hydrogen peroxide vapor room decontamination on Clostridium difficile environmental contamination and transmission in a healthcare setting. Infect Control Hosp Epidemiol 2008;29:723-9.

62. French GL, Otter JA, Shannon KP, Adams NM, Watling D, Parks MJ. Tackling contamination of the hospital environment by methicillin-resistant Staphylococcus aureus (MRSA): a comparison between conventional terminal cleaning and hydrogen peroxide vapour decontamination. J Hosp Infect 2004; $57: 31-7$

63. Bartels MD, Kristoffersen K, Slotsbjerg T, Rohde SM, Lundgren B, Westh H. Environmental methicillin-resistant Staphylococcus aureus (MRSA) disinfection using dry-mist-generated hydrogen peroxide. J Hosp Infect 2008;70:35-41.

64. Hall L, Otter JA, Chewins J, Wengenack NL. Use of hydrogen peroxide vapor for deactivation of Mycobacterium tuberculosis in a biological safety cabinet and a room. J Clin Microbiol 2007;45:810-5.

65. Hardy KJ, Gossain S, Henderson N, Drugan C, Oppenheim BA, Gao F, et al. Rapid recontamination with MRSA of the environment of an intensive care unit after decontamination with hydrogen peroxide vapour. J Hosp Infect 2007;66:360-8.

66. Johnston MD, Lawson S, Otter JA. Evaluation of hydrogen peroxide vapour as a method for the decontamination of surfaces contaminated with Clostridium botulinum spores. J Microbiol Methods 2005:60:403-11.

67. Heckert RA, Best M, Jordan LT, Dulac GC, Eddington DL, Sterritt WG. Efficacy of vaporized hydrogen peroxide against exotic animal viruses. Appl Environ Microbiol 1997;63:3916-8.

68. Klapes NA, Vesley D. Vapor-phase hydrogen peroxide as a surface decontaminant and sterilant. Appl Environ Microbiol 1990;56:503-6.

69. Bates CJ, Pearse R. Use of hydrogen peroxide vapour for environmental control during a Serratia outbreak in a neonatal intensive care unit. J Hosp Infect 2005;61:364-6.

70. Shapey S, Machin K, Levi K, Boswell TC. Activity of a dry mist hydrogen peroxide system against environmental Clostridium difficile contamination in elderly care wards. J Hosp Infect 2008;70:136-41.

71. Falagas ME, Thomaidis PC, Kotsantis IK, Sgouros K, Samonis G, Karageorgopoulos DE. Airborne hydrogen peroxide for disinfection of the hospital environment and infection control: a systematic review. J Hosp Infect 2011;78:171-7.

72. Passaretti CL, Otter JA, Reich NG, Myers J, Shepard J, Ross T, et al. An evaluation of environmental decontamination with hydrogen peroxide vapor for reducing the risk of patient acquisition of multidrug-resistant organisms. Clin Infect Dis 2013;56:27-35.

73. Levin JRL, Parrish C, English D, Ahn S. The effect of portable pulsed xenon ultraviolet light after terminal cleaning on hospital-associated Clostridium difficile infection in a community hospital. Am J Infect Control 2013;42:586-90. 
74. Haas JP, Menz J, Dusza S, Montecalvo MA. Implementation and impact of ultraviolet environmental disinfection in an acute care setting. Am J Infect Control 2014;42:586-90

75. Weber DJ, Rutala WA, Anderson D, Chen L, Sickbert-Bennett EE, Boyce JM. Effectiveness of UV lights and hydrogen peroxide systems for terminal room disinfection: focus on clinical trials. Am J Infect Control 2016;44:e77-84.

76. Salgado CD, Sepkowitz KA, John JF, Cantey JR, Attaway HH, Freeman KD, et al. Copper surfaces reduce the rate of healthcare-acquired infections in the intensive care unit. Infect Control Hosp Epidemiol 2013;34:479-86.
77. Weber DJ, Rutala WA. Self-disinfecting surfaces: review of current methodologies and future prospects. Am J Infect Control 2013;41(Suppl):S31-5.

78. Tamimi AH, Carlino S, Gerba CP. Long-term efficacy of a self-disinfecting coating in an intensive care unit. Am J Infect Control 2014;42:1178-81.

79. Bache SE, Maclean M, MacGregor SJ, Anderson JG, Gettinby G, Coia JE, et al Clinical studies of the high-intensity narrow-spectrum light environmental decontamination system (HINS-light EDS), for continuous disinfection in the burn unit inpatient and outpatient settings. Burns 2012;38: 69-76. 